\title{
Knowledge Regarding Carbon Footprints of Rural Households
}

\author{
Neeta Lodha* and Sudha Vijayvergiya \\ Department of Family Resource Management, College of Home Science, MPUAT, Udaipur \\ (Rajasthan) -313001, India \\ *Corresponding author
}

\section{A B S T R A C T}

\section{Keywords}

Carbon knowledge,

Carbon footprint, GHG, Emissions

Article Info

Accepted:

20 May 2020

Available Online:

10 June 2020
The world is facing the challenge of global warming and climate change issues. Environment has been undergoing significant changes due to increasing human population and its activities which, directly and indirectly release GHG into the atmosphere. When fossil fuels are used to generate energy, forest are cut down and burned, carbon dioxide is produced. Even meeting cooking energy requirement through fuel wood, it is a chief source of releasing GHG into the atmosphere. Our day to day activities are dependent on electricity which is mostly coming from coal based, diesel and petrol for our vehicles and LPG for cooking in our kitchen. All of the energy we use is derived from these fossil fuels which are GHG intensive. The present study aims to assess carbon footprint in rural households of Udaipur District. For this purpose, a sample of 120 rural women of 25-50 years age group from four villages (two Blocks) of Udaipur District were selected. The study was conducted in two phases. In the first phase, household survey was conducted to gather information regarding respondents' family background, their household fuel consumption pattern, carbon habits and knowledge, and also household carbon footprints of the respondents was calculated. In the second phase educational package was developed. The findings of the study succinctly revealed that respondents average secondary carbon footprint score was 80.06. Only one fifth of the respondents had good secondary carbon footprint scores. Habits play an important role in determining individual's carbon footprint. The overall mean score of respondents habits related to carbon footprint was 179.02. Moreover, only one third of the respondents had good habits related to carbon footprint. Near about half of the respondents had average knowledge regarding carbon footprint. The average carbon footprint of the respondents was 38.36 metric tonnes which is significant in increasing greenhouse gases leading to global warming. Therefore, rural women should be imparted knowledge related to clean fuels so that they can contribute in reducing the carbon footprint leading to global warming and thus climate change.

\section{Introduction}

Carbon dioxide is most important greenhouse gas - it traps the sun's heat and keeps the earth warm. Too much $\mathrm{CO}_{2}$ in the air leads to climate change, also known as global warming. The anthropogenic driven climate change is increasing concentration of GHGs 
in the atmosphere. The burning of fossil fuels like coal and petroleum products in homes, transport and industry and deforestation release a lot of $\mathrm{CO}_{2}$ gas into the air (Tuffer, 2011).

Carbon footprints usually mean carbon dioxide $\left(\mathrm{CO}_{2}\right)$ emissions. Carbon dioxide is released when we burn carbon-based fuels. The carbon footprint concept has become a popular tool to estimate GHG (green house gas) emission arising directly and indirectly from the activities of individuals and households. It is important because they are ultimately the main consumers of the energy, food and other goods and services that produce these emissions (Carbon Trust, 2008). The choices individuals make in their homes, travel, the food they eat, what they buy and throw away all influence household carbon footprint and which help to ensure a stable climate for future generations. Knowledge of individuals regarding carbon footprints help and motivate households to reduce carbon footprints. The most common way to reduce the carbon footprint of human is to reduce, reuse and recycle. It is best to properly recycle the disposable items after use (William et al., 2011; Ramachandra and Mala, 2012).

Each individual and household is responsible for a carbon footprint based on the actions of everyday life. Knowledge of rural households' carbon footprint helps to understand their impact on the environment and more importantly, find easy ways to reduce that impact and explore how to live more sustainably. Individual's knowledge regarding carbon footprint and selecting energy-efficient options can reduce greenhouse gas emissions in ways that do not compromise comfort and quality of the life of rural households. Hence, the present paper aims is to ascertain respondents' knowledge regarding carbon footprint.

\section{Materials and Methods}

The study was carried out in nearby two blocks of Udaipur district where the impact of advancement can be seen for assessment of carbon footprint in rural households. The criteria used for selection of villages were proximity of the villages within $100 \mathrm{kms}$. On this basis two villages were selected randomly from each of the selected blocks. Thus four villages were selected randomly on the basis of convenience of transportation, electrification etc.

A sample of 120 households was selected from these four villages. From each selected village a sample of 30 respondents was selected randomly to collect information regarding their family background and knowledge related to carbon footprint. The unit of inquiry was rural households and rural homemakers were the key informants. Data was collected from the rural women of 20-50 years of age because they were well acquainted with the new advanced technologies. An interview technique was used for data collection as it ensures face to face discussion and in-depth information regarding homemakers' family background and carbon emission knowledge.

For assessment of the respondent's knowledge regarding carbon footprint statements were prepared regarding household's fuel, heating, appliances, electricity, transportation used and waste produced. The scale had 67 statements which were judged on the basis of dichotomous answer as 'possessed knowledge' or 'not possessed knowledge'. These statements on the basis of scores were further divided as poor, average and good knowledge of the respondents regarding household carbon footprint heating, electricity, transportation, appliances. The coefficient of validity of knowledge scale was found to be "0.917". 
The split half method was used to establish reliability. The reliability co-efficient ' $\mathrm{r}$ ' obtained for knowledge scale was " 0.841 ". Weighted mean score of the respondents' knowledge regarding various aspects related to cooking heating, appliances, transportation electricity was also calculated.

\section{Results and Discussion}

\section{Family background Information}

More than two third of the respondents were Hindus (66.66 per cent) and rest of them were Muslims (33.33 per cent). The mean age of the respondents was39.16 years $(\mathrm{Sd}=8.00)$. More than half of the respondents (55.83 per cent) belong to middle age group. Moreover, one fourth of the respondents ( 25 per cent) belong to higher age group. One fifth of the respondents (19.17 per cent) belong to lower age group. Less than half of the respondents were educated up to senior secondary (41.66 per cent). However, a nominal percentage of the respondents (16.66 per cent) were educated up to higher secondary. Surprisingly, though respondents reside in nearby city area villages but their percentage of higher education was quite low. Only 8.33 per cent respondents were graduates.

The average size of the respondents' family was 4 members $(\mathrm{Sd}=1.60)$. Minor difference was seen between the respondents' having average family size (45.83 per cent) and large families (41.66 per cent). However, one fourth of the respondents (12.50 per cent) had very small family size. Furthermore, two third of the respondents belonged to joint families and more than one third were from nuclear families ( 37.50 per cent). A contrast variation was seen between the employed (66.66 per cent) and non employed (33.34 per cent) respondents. The respondents were employed as agricultural/MGNERGA laborers, anganwadi worker, peon, nurse, teacher, tailor, shop keeper (grocery, flour mill etc.).
Income is an important human resource which determines the consumption pattern of the households which ultimately leads to carbon footprint emission. The average annual income of respondents' was rupees INR $44,433.33$ ( $\mathrm{Sd}=40,915.00)$. Near about two third of the respondents' belongs to lower income group (62.50 per cent). Moreover, a small percentage of the respondents $(12.00$ per cent) were from higher income group. Respondents average household income was INR 10, 6,641.70 $(\mathrm{Sd}=85337.27)$. Half of the respondents were from lower income group. One third of the respondents (33.33 per cent) belong to middle income group. The average per capita annual income of respondents household was INR 2,43,557.80 $(S d=45202.76)$. Less than half of the respondents belong to lower category of per capita income group (41.67 per cent). Only one fourth of the respondents belong to average category of per capita income group.

\section{Knowledge regarding carbon footprints}

The knowledge of the respondents was judged on dichotomous knowledge test administered to them with responses as 'knowledge possessed' and 'not possessed'. In the test negative and positive statements were there. Positive statements were scored ' 2 ' ' and negative as ' 1 '. The minimum scores that could be obtained by the respondents were ' 67 ' and maximum score were '134'. The correct responses reflected that the knowledge was possessed by the respondents and the incorrect as no knowledge possessed by the respondents. The knowledge of the respondents was judged on the various aspects of household carbon footprints which were categorized under following categories i.e. cooking, appliances, transportation and waste. The knowledge of the respondents on these aspects related to household carbon footprints were compared on the basis of mean scores obtained by them on each item. 


\section{Cooking}

To test the knowledge of respondents regarding cooking and heating it has 16 statements were selected. Table 1 data revealed that respondents posses knowledge regarding "Covering a utensil/pot with lid will save cooking time and fuel (83.33 per cent)", "Soaking pulses and cereals save cooking time and fuel (83.33 per cent)" and "Cooking fuel in presser cooker save fuels $(75.00$ per cent)". On the contrary, respondents had no knowledge regarding "Cooking igniting heat source save fuel" (83.33 per cent)", "Make sure that the flame is colour less or blue (75.00 per cent)", "Frozen foodstuff should be brought to room temperature before heating will save fuel (75.00 per cent)" and "Cut food into smaller pieces save fuel will reduce cooking time (75.00 per cent)".

While comparing the mean scores, the highest mean score was obtained for "Covering a utensil/pot with lid will save cooking time and fuel (mean score=1.83)" followed by "Soaking pulses and cereals save cooking time and fuel (mean score=1.83)" and "Cooking fuel in presser cooker save fuels (mean score=1.75)" respectively.

The respondents were found to have poor knowledge for "Cut food into smaller pieces save fuel will reduce cooking time (mean score $=1.17)$ ", "Reheating of food destroy nutrients of the foodstuff and consumes fuel also (mean score=1.17)", "Use metal (stainless pans) not clay pans for cooking (mean score $=1.17$ )" and "Cooking igniting heat source save fuel (mean score=1.17)".

\section{Appliances}

To test the knowledge of respondents regarding appliances used, 32 statements were administered. The findings revealed that more than three fourth of the respondents had knowledge of "Frequent opening of the door lowers temperature (83.33 per cent)", "Use of Argo- net in the house controls interior temperature and reduce carbon footprint (83.33 per cent)" and "Microwave oven shortens cooking times which save energy (75.00 per cent)". Respondents had no knowledge regarding "Frequent opening the refrigerator door will consumes more electricity (91.66 per cent)", "Turn off the room lights when not in use (91.66 per cent)", "Use energy efficient star rated appliance will save energy" (83.33 per cent)", "Frequent opening of the door lowers temperature (83.33 per cent)", "Use of fans will reduce carbon footprint (83.33 per cent)".

While comparing the mean scores, the highest mean score obtained for the statements was "Frequent opening of the door lowers temperature (mean score= 1.42)", "Use of cold water for rinsing clothes saves electricity (mean score $=1.42)$ ", "Use the minimum amount of water when boiling food save fuel (mean score $=1.42)$ " and "Baking large food items in microwave consumes more electricity (mean score $=1.42$ )", followed by "Cover the water heating pot will save fuel (mean score $=1.37$ )" and then respectively.

The respondents were found to have lower intensity score for "Switch on the fan only when actually needed will save electricity (mean score $=1.10)$ ", "Don't open the room door frequently (mean score $=1.10)$ ", "Unplug electric items when not in use save electricity (mean score $=1.10)$ ", "Keeping electronic equipment on standby mode consumes electricity (mean score $=1.10$ )", "Turn off lights T. V., DVD player, Hi fi, computer when not in use (mean score $=1.10$ )", "Turn off the room lights when not in use (mean score $=1.10)$ ", and "Clean filters regularly will increase cooling of the room (mean score=1.10)". 
Table.1 Distribution of respondents according to their knowledge related to cooking and heating

\begin{tabular}{|c|c|c|c|c|c|c|}
\hline \multirow{3}{*}{$\begin{array}{l}\text { S. } \\
\text { No. }\end{array}$} & \multirow{3}{*}{$\begin{array}{l}\text { Knowledge Statements Related to Cooking and } \\
\text { Heating }\end{array}$} & \multicolumn{4}{|c|}{ Knowledge } & \multirow{3}{*}{$\begin{array}{l}\text { Item Intensity } \\
\text { Score (mean } \\
\text { score out of } 2 \text { ) }\end{array}$} \\
\hline & & \multicolumn{2}{|c|}{ Possessed } & \multicolumn{2}{|c|}{ Not Possessed } & \\
\hline & & $\mathbf{f}$ & $\%$ & $\mathbf{f}$ & $\%$ & \\
\hline 1. & Cooking igniting heat source save fuel. & 20 & 16.66 & 100 & 83.33 & 1.17 \\
\hline 2. & Cooking fuel in presser cooker save fuels & 90 & 75.00 & 30 & 25.00 & 1.75 \\
\hline 3. & Do not overcook vegetables. & 70 & 58.33 & 50 & 41.66 & 1.58 \\
\hline 4. & Use metal (stainless pans) not clay pans for cooking. & 20 & 16.66 & 100 & 83.33 & 1.17 \\
\hline 5. & $\begin{array}{l}\text { Covering a utensil/pot with lid will save cooking time } \\
\text { and fuel. }\end{array}$ & 100 & 83.33 & 20 & 16.66 & 1.83 \\
\hline 6. & $\begin{array}{l}\text { Soaking pulses and cereals save cooking time and } \\
\text { fuel. }\end{array}$ & 100 & 83.33 & 20 & 16.66 & 1.83 \\
\hline 7. & Reduce flame when cooking boiling starts to save fuel. & 40 & 40.33 & 80 & 66.66 & 1.33 \\
\hline 8. & Make sure that the flame is colour less or blue. & 30 & 25.00 & 90 & 75.00 & 1.25 \\
\hline 9. & Food should be ready before turning the burner. & 50 & 41.66 & 70 & 58.33 & 1.42 \\
\hline 10. & $\begin{array}{l}\text { Turn off gas immediately after completion of food } \\
\text { cooking. }\end{array}$ & 50 & 41.66 & 70 & 58.33 & 1.42 \\
\hline 11. & $\begin{array}{l}\text { Reheating of food destroy nutrients of the foodstuff } \\
\text { and consumes fuel also. }\end{array}$ & 20 & 16.66 & 100 & 83.34 & 1.17 \\
\hline 12. & $\begin{array}{l}\text { Frozen foodstuff should be brought to room } \\
\text { temperature before heating will save fuel. }\end{array}$ & 30 & 25.00 & 90 & 75.00 & 1.24 \\
\hline 13. & $\begin{array}{l}\text { Cut food into smaller pieces save fuel will reduce } \\
\text { cooking time. }\end{array}$ & 20 & 16.66 & 100 & 75.00 & 1.17 \\
\hline 14. & $\begin{array}{l}\text { Use the minimum amount of water when boiling food } \\
\text { save fuel. }\end{array}$ & 50 & 41.66 & 70 & 58.33 & 1.42 \\
\hline 15. & $\begin{array}{l}\text { Slow the flame after water/liquid boils when will save } \\
\text { fuel }\end{array}$ & 43 & 35.80 & 77 & 64.17 & 1.36 \\
\hline 16. & Cover the water heating pot will save fuel. & 43 & 35.80 & 77 & 64.17 & 1.37 \\
\hline \multicolumn{6}{|c|}{ Total Weighted Mean Score } & 1.40 \\
\hline
\end{tabular}

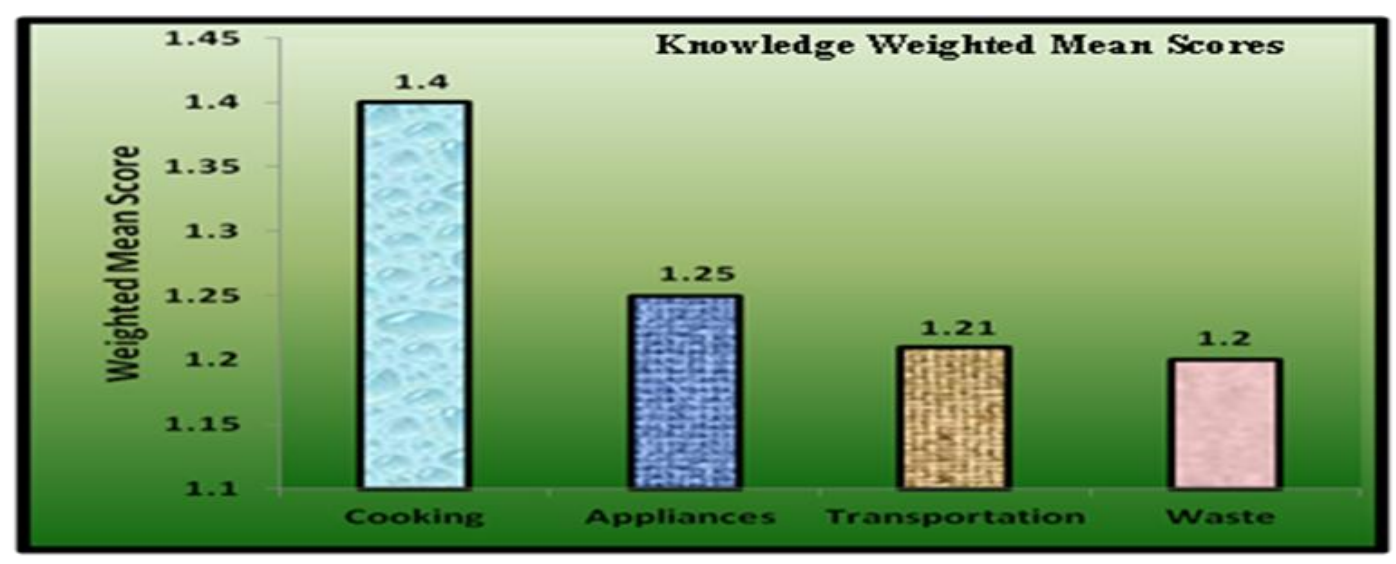

Fig.1. Respondents Carbon Footprint Knowledge 
Table.2 Distribution of respondents according to their knowledge related to appliances used

\begin{tabular}{|c|c|c|c|c|c|c|}
\hline \multirow{3}{*}{$\begin{array}{l}\text { S. } \\
\text { No. }\end{array}$} & \multirow{3}{*}{$\begin{array}{c}\text { Knowledge Statements Related Appliances } \\
\text { Used }\end{array}$} & \multicolumn{4}{|c|}{ Knowledge } & \multirow{3}{*}{$\begin{array}{l}\text { Item Intensity } \\
\text { Score (mean } \\
\text { score out of } 2 \text { ) }\end{array}$} \\
\hline & & \multicolumn{2}{|c|}{ Possessed } & \multicolumn{2}{|c|}{ Not Possessed } & \\
\hline & & f & $\%$ & f & $\%$ & \\
\hline 1. & $\begin{array}{l}\text { Baking large food items in microwave } \\
\text { consumes more electricity. }\end{array}$ & 40 & 16.66 & 80 & 66.66 & 1.42 \\
\hline 2. & $\begin{array}{l}\text { Microwave oven shortens cooking times which } \\
\text { save energy. }\end{array}$ & 30 & 75.00 & 90 & 75.00 & 1.35 \\
\hline 3. & $\begin{array}{l}\text { Frequent opening the microwave door to check } \\
\text { food condition will leads to temperature drop. }\end{array}$ & 40 & 58.33 & 80 & 66.66 & 1.32 \\
\hline 4. & $\begin{array}{l}\text { Keeping the oven door closed while cooking } \\
\text { saves fuel. }\end{array}$ & 50 & 16.66 & 70 & 58.33 & 1.33 \\
\hline 5. & $\begin{array}{l}\text { Frequent opening of the door lowers } \\
\text { temperature. }\end{array}$ & 20 & 83.33 & 100 & 83.33 & 1.33 \\
\hline 6. & $\begin{array}{l}\text { Frequent opening the refrigerator door will } \\
\text { onsumes more electricity. }\end{array}$ & 10 & 40.33 & 110 & 91.66 & 1.42 \\
\hline 7. & $\begin{array}{l}\text { Leaving the refrigerator door open for longer } \\
\text { time than necessary will escape the cold air. }\end{array}$ & 50 & 25.00 & 70 & 58.33 & 1.30 \\
\hline 8. & $\begin{array}{l}\text { Loose refrigerator door seal causes unit to } \\
\text { work harder and use more energy. }\end{array}$ & 40 & 41.66 & 80 & 66.66 & 1.30 \\
\hline 9. & $\begin{array}{l}\text { Select right size of refrigerator according to } \\
\text { family needs will save electricity. }\end{array}$ & 0 & 41.66 & 120 & 100 & 1.36 \\
\hline 10. & $\begin{array}{l}\text { Fully filled pot with butter milk while } \\
\text { churning will save electricity. }\end{array}$ & 76 & 63.66 & 44 & 36.66 & 1.63 \\
\hline 11. & Natural drying of clothes will save electricity. & 76 & 63.66 & 44 & 36.66 & 1.63 \\
\hline 12. & $\begin{array}{l}\text { Use of cold water for rinsing clothes saves } \\
\text { electricity. }\end{array}$ & 100 & 16.66 & 20 & 16.66 & 1.42 \\
\hline 13. & $\begin{array}{l}\text { Washing clothes with only full load will saves } \\
\text { water and electricity. }\end{array}$ & 40 & 41.66 & 80 & 66.66 & 1.36 \\
\hline 14. & $\begin{array}{l}\text { Use the minimum amount of water when } \\
\text { boiling food save fuel. }\end{array}$ & 60 & 50.00 & 60 & 50.00 & 1.42 \\
\hline 15. & $\begin{array}{l}\text { Slow the flame after water/liquid boils when } \\
\text { will save fuel. }\end{array}$ & 45 & 37.50 & 75 & 62.50 & 1.36 \\
\hline 16. & Cover the water heating pot will save fuel. & 45 & 37.50 & 70 & 62.50 & 1.37 \\
\hline 17. & $\begin{array}{l}\text { Planning tree inside the house will reduce } \\
\text { temperature. }\end{array}$ & 50 & 41.66 & 70 & 58.33 & 1.10 \\
\hline 18. & $\begin{array}{l}\text { Switch on the fan only when actually needed } \\
\text { will save electricity. }\end{array}$ & 50 & 41.66 & 70 & 58.33 & 1.10 \\
\hline 19. & $\begin{array}{l}\text { Switch off the fan when leaving room will } \\
\text { save electricity. }\end{array}$ & 70 & 58.33 & 50 & 41.66 & 1.10 \\
\hline 20. & $\begin{array}{l}\text { Use of Argo- net in the house controls interior } \\
\text { temperature and reduce carbon footprint. }\end{array}$ & 100 & 83.33 & 20 & 16.66 & 1.24 \\
\hline 21. & Use of fans will reduce carbon footprint. & 20 & 16.66 & 100 & 83.33 & 1.24 \\
\hline 22. & Seal doors and windows air tight before & 30 & 25.00 & 90 & 75 & 1.24 \\
\hline
\end{tabular}




\begin{tabular}{|c|c|c|c|c|c|c|}
\hline & switching on the A. C. & & & & & \\
\hline 23. & Don’t open the room door frequently. & 50 & 41.66 & 70 & 58.33 & 1.10 \\
\hline 24. & $\begin{array}{l}\text { Clean filters regularly will increase cooling of } \\
\text { the room. }\end{array}$ & 30 & 25.00 & 90 & 75 & 1.10 \\
\hline 25. & $\begin{array}{l}\text { Unplug electric items when not in use save } \\
\text { electricity. }\end{array}$ & 30 & 25.00 & 90 & 75 & 1.10 \\
\hline 26. & $\begin{array}{l}\text { Turn off lights T. V., DVD player. Hi fi, } \\
\text { computer when not in use. }\end{array}$ & 75 & 62.5 & 45 & 37.5 & 1.10 \\
\hline 27. & $\begin{array}{l}\text { Keeping electronic equipment on standby } \\
\text { mode consumes electricity. }\end{array}$ & 60 & 50.00 & 60 & 50.00 & 1.10 \\
\hline 28. & $\begin{array}{l}\text { Use energy efficient star rated appliance will } \\
\text { save energy. }\end{array}$ & 20 & 16.66 & 100 & 83.33 & 1.10 \\
\hline 29. & Turn off the room lights when not in use. & 10 & 8.33 & 110 & 91.66 & 1.10 \\
\hline 30. & $\begin{array}{l}\text { Use energy efficient compact fluorescent } \\
\text { lamps and LED ( light emitting denote). }\end{array}$ & 80 & 66.66 & 40 & 33.33 & 1.10 \\
\hline 31. & $\begin{array}{l}\text { Clean lighting fixture regularly maintains } \\
\text { illumination. }\end{array}$ & 45 & 37.5 & 75 & 62.5 & 1.26 \\
\hline 32. & $\begin{array}{l}\text { Use electronic chokes in place off } \\
\text { condensational copper chokes. }\end{array}$ & 30 & 25.00 & 90 & 70.00 & 1.26 \\
\hline \multicolumn{6}{|c|}{ Total Weighted Mean Score } & 1.25 \\
\hline
\end{tabular}

Table.3 Distribution of respondents according to their knowledge related to transportation

\begin{tabular}{|c|c|c|c|c|c|c|}
\hline \multirow{3}{*}{ S. No. } & \multirow{3}{*}{$\begin{array}{c}\text { Knowledge Statements Related to Carbon } \\
\text { Footprints }\end{array}$} & \multicolumn{4}{|c|}{ Knowledge } & \multirow{3}{*}{$\begin{array}{c}\text { Item } \\
\text { Intensity } \\
\text { Score (out } \\
\text { of 2) }\end{array}$} \\
\hline & & \multicolumn{2}{|c|}{ Possessed } & \multicolumn{2}{|c|}{ Not Possessed } & \\
\hline & & f & $\%$ & f & $\%$ & \\
\hline 1. & Regularly checked tyre & 50 & 41.66 & 70 & 58.33 & 1.25 \\
\hline 2. & $\begin{array}{l}\text { Do not use congested routes and rush hour while } \\
\text { travelling }\end{array}$ & 10 & 8.33 & 110 & 91.66 & 1.58 \\
\hline 3. & Switch off the vehicle at red traffic light save fuel & 30 & 25.00 & 90 & 75.00 & 1.17 \\
\hline 4. & $\begin{array}{l}\text { Use own vehicle for travelling short distances } \\
\text { save fuel }\end{array}$ & 50 & 41.66 & 70 & 58.33 & 1.42 \\
\hline 5. & $\begin{array}{l}\text { Weekly shopping in a single trip save fuel (petrol } \\
\text { and diesel) }\end{array}$ & 40 & 33.33 & 80 & 66.66 & 1.17 \\
\hline 6. & $\begin{array}{l}\text { Use of private transportation saves fuel for } \\
\text { travelling }\end{array}$ & 30 & 25.00 & 90 & 75.00 & 1.04 \\
\hline 7. & Use of cycle or walk saves fuel & 100 & 83.33 & 20 & 16.66 & 1.04 \\
\hline 8. & $\begin{array}{l}\text { Use bus and train rather than car for travelling } \\
\text { long distances }\end{array}$ & 75 & 62.50 & 45 & 37.5 & 1.17 \\
\hline 9. & $\begin{array}{l}\text { Pool car for work or kids school saves fuel } \\
\text { consumption }\end{array}$ & 30 & 25.00 & 90 & 75.00 & 1.17 \\
\hline \multicolumn{6}{|c|}{ Total Weighted Mean Score } & 1.21 \\
\hline
\end{tabular}


Table.4 Distribution of respondents according to their knowledge related to waste disposal and use

\begin{tabular}{|c|c|c|c|c|c|c|}
\hline \multirow{4}{*}{ S. No. } & \multirow{4}{*}{$\begin{array}{c}\text { Knowledge Statements Related to Waste } \\
\text { Disposal and Use }\end{array}$} & \multicolumn{5}{|c|}{$\mathrm{n}=120$} \\
\hline & & \multicolumn{4}{|c|}{ Knowledge } & \multirow{3}{*}{$\begin{array}{c}\text { Item } \\
\text { Intensity } \\
\text { Score } \\
\text { (out of } 2)\end{array}$} \\
\hline & & \multicolumn{2}{|c|}{ Possessed } & \multicolumn{2}{|c|}{ Not Possessed } & \\
\hline & & $\mathbf{f}$ & $\%$ & $\mathbf{f}$ & $\%$ & \\
\hline 1. & Recycle gray water & 30 & 25.00 & 90 & 75.00 & 1.25 \\
\hline 2. & Re-use old products like clothes and cans & 70 & 58.33 & 50 & 41.67 & 1.58 \\
\hline 3. & Kitchen waste is used for compost making & 20 & 16.66 & 100 & 83.33 & 1.17 \\
\hline 4. & Use reusable shopping bags & 50 & 41.66 & 70 & 58.33 & 1.42 \\
\hline 5. & Use rechargeable batteries. & 20 & 16.66 & 100 & 83.33 & 1.17 \\
\hline 6. & $\begin{array}{l}\text { Do not buy bottle water if tap water is safe to } \\
\text { drink. }\end{array}$ & 5 & 4.16 & 115 & 95.83 & 1.04 \\
\hline 7. & Don’t use polystyrene or plastic cups. & 5 & 4.16 & 115 & 95.83 & 1.04 \\
\hline 8. & Don’t use ceramic and clay mugs. & 5 & 4.16 & 115 & 95.83 & 1.04 \\
\hline 9. & Don’t use restricted pesticides. & 20 & 16.66 & 100 & 83.33 & 1.17 \\
\hline 10. & $\begin{array}{l}\text { Household waste like old paper, bottles and } \\
\text { cans are given for recycling. }\end{array}$ & 20 & 16.66 & 100 & 83.33 & 1.17 \\
\hline \multicolumn{6}{|c|}{ Total Weighted Mean Score } & 1.20 \\
\hline
\end{tabular}

Table.5 Distribution of respondents according to their knowledge weighted mean score related to household carbon footprints

\begin{tabular}{|c|c|c|}
\hline S. No. & $\begin{array}{l}\text { Knowledge Related to Household Carbon } \\
\text { Footprint }\end{array}$ & $\begin{array}{l}\text { Knowledge } \\
\text { Weighted Mean Score }\end{array}$ \\
\hline 1. & Cooking & 1.40 \\
\hline 2. & Appliances & 1.25 \\
\hline 3. & Transportation & 1.21 \\
\hline \multirow[t]{2}{*}{4.} & Waste & 1.20 \\
\hline & Total Weighted Mean Score & 1.50 \\
\hline
\end{tabular}

Table.6 Distribution of respondents according to their level of knowledge related to household carbon footprint

\begin{tabular}{|c|l|c|c|}
\hline S. No. & \multicolumn{1}{|c|}{ Level of Knowledge (in scores) } & f & \% \\
\hline 1. & Poor knowledge (67-90.68 score) & 40 & 33.33 \\
\hline 2. & Average knowledge (90.69-103.91 score) & 55 & 45.83 \\
\hline 3. & Good knowledge (103.92-134.00 score) & 25 & 20.83 \\
\hline & Total & $\mathbf{1 2 0}$ & $\mathbf{1 0 0}$ \\
\hline & Average & \multicolumn{2}{|c|}{$\mathbf{9 7 . 3 0}$} \\
\hline & SD & \multicolumn{2}{|c|}{} \\
\hline
\end{tabular}

$\mathrm{n}=120$ 


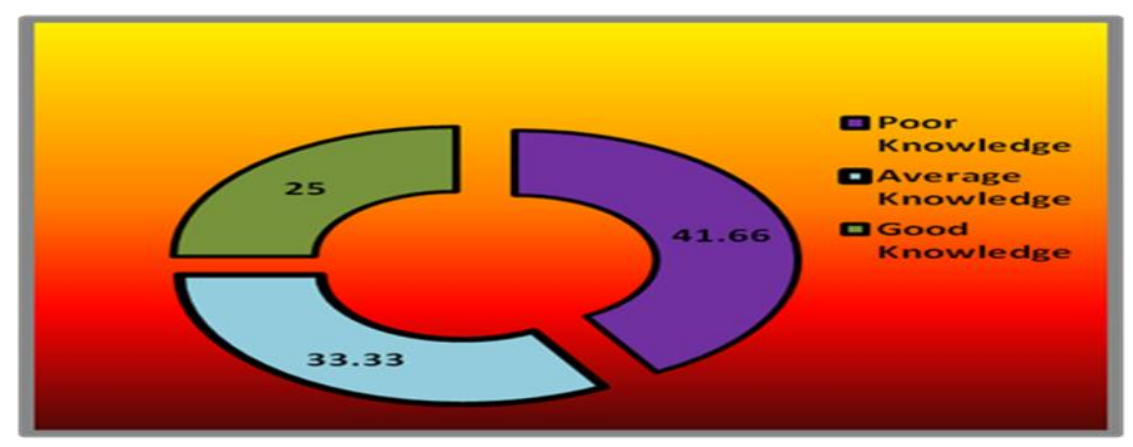

Fig. 2. L evel of Respondents C axbon Knowledge

\section{Transportation}

To test the knowledge of respondents regarding transportation, 9 statements were employed on the respondents. The data revealed that respondents had knowledge of "Use of cycle or walk saves fuel (83.33 per cent)" and "Use bus and train rather than car for travelling long distances (62.50 per cent)".

However, on some of the issues respondents lack knowledge "Do not use congested routes and rush hour while travelling (91.66 per cent)", "Switch off the vehicle at red traffic light save fuel (75.00 per cent)", "Use of private transportation saves fuel for travelling (75.00 per cent)", "Pool car for work or kids school saves fuel consumption (75.00 per cent)".

While comparing the mean scores, the highest mean score was obtained for "Do not use congested routes and rush hour while travelling (mean score=1.58)" Followed by "use own vehicle for travelling short distances save fuel (mean score $=1.42$ )" and then "Regularly checked tyre (mean score $=1.25$ )" respectively. The respondents were found to have lower mean score for "Use of private transportation saves fuel for travelling (mean score $=1.04)$ " and "Use of cycle or walk saves fuel (mean score=1.04)".

\section{Waste}

To test the knowledge of respondents regarding waste it has 10 statements. The perusal of the data indicates that respondents had knowledge of "Re-use old products like clothes and cans (58.33 per cent)". However, respondents had no knowledge of "Do not buy bottle water if tap water is safe to drink (95.83 per cent)", "Don't use polystyrene or plastic cups (95.83 per cent)"and "Don't use ceramic and clay mugs (95.83 per cent)".

While comparing the mean scores, the highest mean score was obtained for "Re-use old products like clothes and cans (mean score=1.58)" followed by "use reusable shopping bags (mean score=1.42)" and then "recycle gray water (mean score $=1.25$ )" respectively. The respondents were found to have lower mean item intensity score for "Do not buy bottle water if tap water is safe to drink (mean score=1.04)", "Don't use polystyrene or plastic cups (mean score $=1.04)$ " and "Don't use ceramic and clay mugs (mean score=1.04)".

\section{Overall weighted mean score}

Overall knowledge of the respondents was based on the four aspects related to carbon footprints i.e. cooking, appliances, transportation and waste. The summated weighted mean score in totality on the four aspects related to carbon footprints highlighted that the aspects related to cooking (mean score $=1.40$ ) ranked first in the knowledge of the respondents followed by 
appliances (mean score $=1.25)$ then by transportation knowledge (mean score $=1.21$ ) and lastly by waste disposal (mean score $=1.20)$. It can be said that the findings related to knowledge by the respondents were not in corroboration with the habits possessed by the respondents on the carbon footprints.

\section{Respondents level of knowledge related to household carbon footprints}

The overall mean score regarding respondents knowledge related to carbon footprint was 97.30 ( $\mathrm{Sd}=6.61)$. Interestingly, 45.83 per cent had average and 33.33 per cent of the respondents' had poor knowledge regarding carbon footprint. It was surprising to note that only small percentage of the respondents had good knowledge (20.83 per cent) regarding carbon footprint.

In conclusion, carbon footprint reflects the amount of carbon dioxide $\left(\mathrm{CO}_{2}\right)$ that an individual produces in her daily activities by burning fossil fuels, transportation, electricity and more. Rural households have poor knowledge related to household carbon footprint related to cooking, appliances use, transportation and waste disposal. They should be imparted knowledge related to clean fuels so that homemakers can contribute in reducing the carbon footprints leading to climate change or global warming.

The study recommends reducing the $\mathrm{CO}_{2}$ emission from households by minimizing fuel consumption such as electricity, LPG, coal, petrol etc. These sources of energy are fast diminishing and their reduced use will help in reducing carbon footprint. Households should purchase and make growing use of 'green electricity' measures which are abundantly available in renewable sources such as solar, wind and wave power and 'hot rocks'. There is thus a requirement to educate and reorient the political and the bureaucratic class as well as the average citizen about the dangers of carbon emission. Institutions of higher education can play a major role by initiating efforts at micro level targeting individual and households at societal level through education and awareness campaigns in helping to combat climate change in their social/ extension programmes. The investigation suggests buying locally available foodstuffs which will save $\mathrm{CO}_{2}$. Researchers, academicians, extension workers, NGOs should impart training regarding role of $\mathrm{CO}_{2}$ in global warming and ways to curb it.

\section{References}

Carbon Trust Fourth Report. 2008. Environmental Audit Committee, The Role of Carbon Market in Prevention Dangerous Climate Change. Internet link:

http://www.en.wikipedia.org/wiki/carbo n-emission-trading.

Environment Protection Agency. 2011. Reduce climate change. Internet Link:http://www.epa.gov/climatechange /EPAactivities/regulatoryinitiatives.html

Ramachandra, T. V., and Mala, S. 2012. Decentralized carbon footprint analysis for opting climate change mitigation strategies in India.16(8): 5820-5833.

Tuffer, N. 2011. Carbon emission energy in Fuel Poverty. Internet link: http:// www. Consumer focus. Org.uk? news/ consumer-focus-response-to-toughercarbon-emision-tougher.

Williams. 2007. Public Transportation use should be at the top of the households. 202: 496-4816 Internet Link:http://www.apta.com/mediacenter/ pressreleases/2007/Pages/070926_clima te_report.aspx. 


\section{How to cite this article:}

Neeta Lodha and Sudha Vijayvergiya. 2020. Knowledge Regarding Carbon Footprints of Rural Households. Int.J.Curr.Microbiol.App.Sci. 9(06): 2542-2552.

doi: https://doi.org/10.20546/ijcmas.2020.906.309 